Article

\title{
Pb-Isotopic Study of Galena by LA-Q-ICP-MS: Testing a New Methodology with Applications to Base-Metal Sulphide Deposits
}

\author{
Christopher R. M. McFarlane *, Azam Soltani Dehnavi and David R. Lentz \\ Department of Earth Sciences, University of New Brunswick, Fredericton, NB E3B 5A3, Canada; \\ azam.soltani@unb.ca (A.S.D.); dlentz@unb.ca (D.R.L.) \\ * Correspondence: crmm@unb.ca; Tel.: +1-506-458-7211 \\ Academic Editors: Cristiana L. Ciobanu and Nigel J. Cook \\ Received: 31 May 2016; Accepted: 2 September 2016; Published: 15 September 2016
}

\begin{abstract}
In situ laser ablation quadrupole inductively coupled plasma mass spectrometry was used to measure $\mathrm{Pb}$ isotopes in galena. Data acquisition was optimized by adjusting spot size, energy density, and ablation time to obtain near steady-state low relative standard deviation (\%RSD) signals. Standard-sample bracketing using in-house Broken Hill galena as external reference standard was used and offline data reduction was carried out using VizualAge for Iolite3. Using this methodology, galena grain in polished thin sections from selected massive sulphide deposits of the Bathurst Mining Camp, Canada, were tested and compared to previously published data. Absolute values and errors on the weighted mean of $\sim 20$ individual analyses from each sample compared favourably with whole-rock $\mathrm{Pb}-\mathrm{Pb}$ isotope data. This approach provides a mean to obtain rapid, accurate, and moderately $(0.1 \% 2 \sigma)$ precise $\mathrm{Pb}$ isotope measurements in galena and is particularly well suited for exploratory or reconnaissance studies. Further refinement of this approach may be useful in exploration for volcanogenic massive sulphides deposits and might be a useful vectoring tool when complemented with other conventional exploration techniques.
\end{abstract}

Keywords: Bathurst Mining Camp (BMC); Broken Hill; galena; iolite; LA-Q-ICP-MS; Pb isotopes; vectoring tool; volcanogenic massive sulphides (VMS)

\section{Introduction}

Application of in situ laser ablation inductively coupled plasma mass spectrometry (LA-ICP-MS) in the realm of compositional and isotopic investigations of sulphide minerals has expanded in the last decade [1-5]. The initial $\mathrm{Pb}$ isotope composition of an ore fluid is best determined from $\mathrm{Pb}$-rich minerals genetically associated with the mineralizing event, e.g., galena (initial $\mathrm{U} / \mathrm{Pb}=0$ ) [6-11] as well as pyrite [4,5,12-17], sphalerite [18], chalcopyrite, and pyrrhotite [19]. In contrast to conventional whole-rock $\mathrm{Pb}$ isotope determination of sulphides, which suffers from laborious sample preparation procedures as well as mixing of sulphide phases of potentially disparate petrogenesis, micro-analytical techniques offer the advantage of better textural and intragranular control on the selection of target material. LA-ICP-MS developments continue to be made in terms of Pb-isotope determination $[4,5,20]$. For example, a comparison study by [20] demonstrated the feasibility of analysing $\mathrm{Pb}$ ores (galena) by LA sector-field (SF) ICP-MS. They measured Pb isotope ratios on NBS981 wire at the start, middle, and end of a laser ablation session and obtained errors on the mean of 0.4 on ${ }^{206} \mathrm{~Pb} /{ }^{204} \mathrm{~Pb}$ to $1.2 \%$ on ${ }^{207} \mathrm{~Pb} /{ }^{204} \mathrm{~Pb}$. They also encountered significant bias between $\mathrm{Pb}$ isotope ratios measured by TIMS (thermal ionization mass spectrometry) and LA-SF-ICP-MS with both datasets corrected using NBS981 for mass bias correction, but no documentation of the effect of variable fluence on ablation behaviour was provided by [20]. To date, no investigation of $\mathrm{Pb}$ isotope analyses on galena using an optimized matrix-matched LA-quadrupole (Q) ICP-MS methodology has been conducted. 
Isotope ratios measured by Q-ICP-MS have lower precision compared to multiple-collection (MC)-ICP-MS which can achieve precision $<0.01 \%$. However, if instrumental noise can be minimized and mass bias accurately corrected, single-collector SF-ICP-MS and Q-ICP-MS have been shown to produce reliable and precise $\mathrm{Pb}$-isotope data $[9,20]$. Pooled weighted means for $>20$ individual measurements of moderate $(\sim 0.2$ to $0.4 \% 2 \sigma)$ precision can be used to lower errors even further. Thus, it is theoretically possible to obtain high-precision $(\leq 0.1 \% 2 \sigma) \mathrm{Pb}$-isotope ratios with LA Q-ICP-MS by targeting Pb-rich minerals and optimizing ablation and collection conditions to generate near-steady-state low \%RSD signals. In massive sulphide deposits containing galena, a single polished thin section offers hundreds of potential targets, which, because of the expected homogeneity of $\mathrm{Pb}$-isotopes at this scale, should yield identical isotope ratios. Therefore, the ultimate precision of pooled data is not limited by sample supply, but rather by instrumental conditions that minimize internal errors. In LA-Q-ICP-MS, the stability of the measured $\mathrm{Pb}$ ion beams is a complex function of processes occurring in system components starting at the site of ablation all the way to the ICP-MS detector: pulse-to-pulse laser energy stability, laminar versus turbulent flow in transfer tubing, efficiency of smoothing devices, torch flicker, constant interface region vacuum, ion optics tuning, and quadrupole mass filter settings. This contribution reports on our attempts to optimize these instrumental conditions with the ultimate objective of exploiting this technique for reconnaissance-level $\mathrm{Pb}$-isotope measurements in galena-bearing ore deposits.

Some of the additional challenges involved in $\mathrm{Pb}$-isotope measurement of galena (and other sulphides) in massive sulphide deposits are: (1) textural complexity and occurrence of $\mathrm{Pb}$ - and/or U-bearing inclusions and domains; (2) achieving controlled ablation condition with minimal laser-induced melting; and (3) standardization and choice of data reduction strategy (see [5]). Nevertheless, LA-ICP-MS analysis offers a number of advantages in Pb-isotopic studies of sulphides [5]. First, quadrupole ICP systems are capable of analysing minerals with a wide variety of Pb content due to the large dynamic range (typically nine orders of magnitude) of their detection system. Second, fast sequential measurement of analytes (e.g., $<10 \mathrm{~ms}$ per mass) ensures that time-dependent variations in the ion beam can be captured on a $<0.5 \mathrm{~s}$ timescale. The fast scanning quadrupole filter also allows a broader suite of analytes to be measured beyond just the $\mathrm{Pb}$ masses of interest facilitating identification of $\mathrm{Pb}$-bearing micro-inclusions, such as zircon, monazite, and uraninite. Furthermore, the elemental imaging capability of this technique is a great advantage as it provides quick semi-quantitative data to be used in revealing textural complexities and best selection of single spot targets. Therefore, LA-Q-ICP-MS offers a promising technique to be invested in terms of developments in sulphide $\mathrm{Pb}$-isotopes methodology that could be ultimately incorporated into high-precision LA MC-ICP-MS measurements.

\section{Summary of the Bathurst Mining Camp Geology and Sampling}

Middle Ordovician bimodal volcanic and sedimentary sequences are host to the volcanogenic massive sulphide deposits of the BMC, New Brunswick, Canada. The BMC contains 45 deposits and 95 occurrences, in which 25 deposits are more than $1 \mathrm{Mt}$, including the supergiant Brunswick No. 12, containing a pre-mining massive sulphide resource in excess of $290 \mathrm{Mt}$ ([21] and references therein). The Bathurst Supergroup including Tetagouche, California Lake, and Sheephouse Brook groups, hosted the massive sulphides of the BMC [21]. The Bathurst Supergroup originally formed distinct rift-related basins within the greater Tetagouche-Exploits back-arc basin [21-27] and were subsequently tectonically juxtaposed in a west-dipping subduction complex. The BMC deposits have been affected by the Salinic Orogeny [22] and subsequent Acadian Orogeny [23-27]. Metamorphism varies from lower- to upper greenschist facies with peak metamorphic conditions from 325 to $400{ }^{\circ} \mathrm{C}$ and 6 to 7 kbars [28]. The simplified geological map of the Bathurst Mining Camp, northeastern New Brunswick, showing the location of massive sulphide deposits examined during this study (black circles), is presented in Figure 1 (modified from [26,29]). Samples for this study were selected 
from representative massive sulphide deposits of the BMC, specifically: Brunswick No. 6, Halfmile Lake Deep zone, Key Anacon East zone, Caribou, and Restigouche deposits.

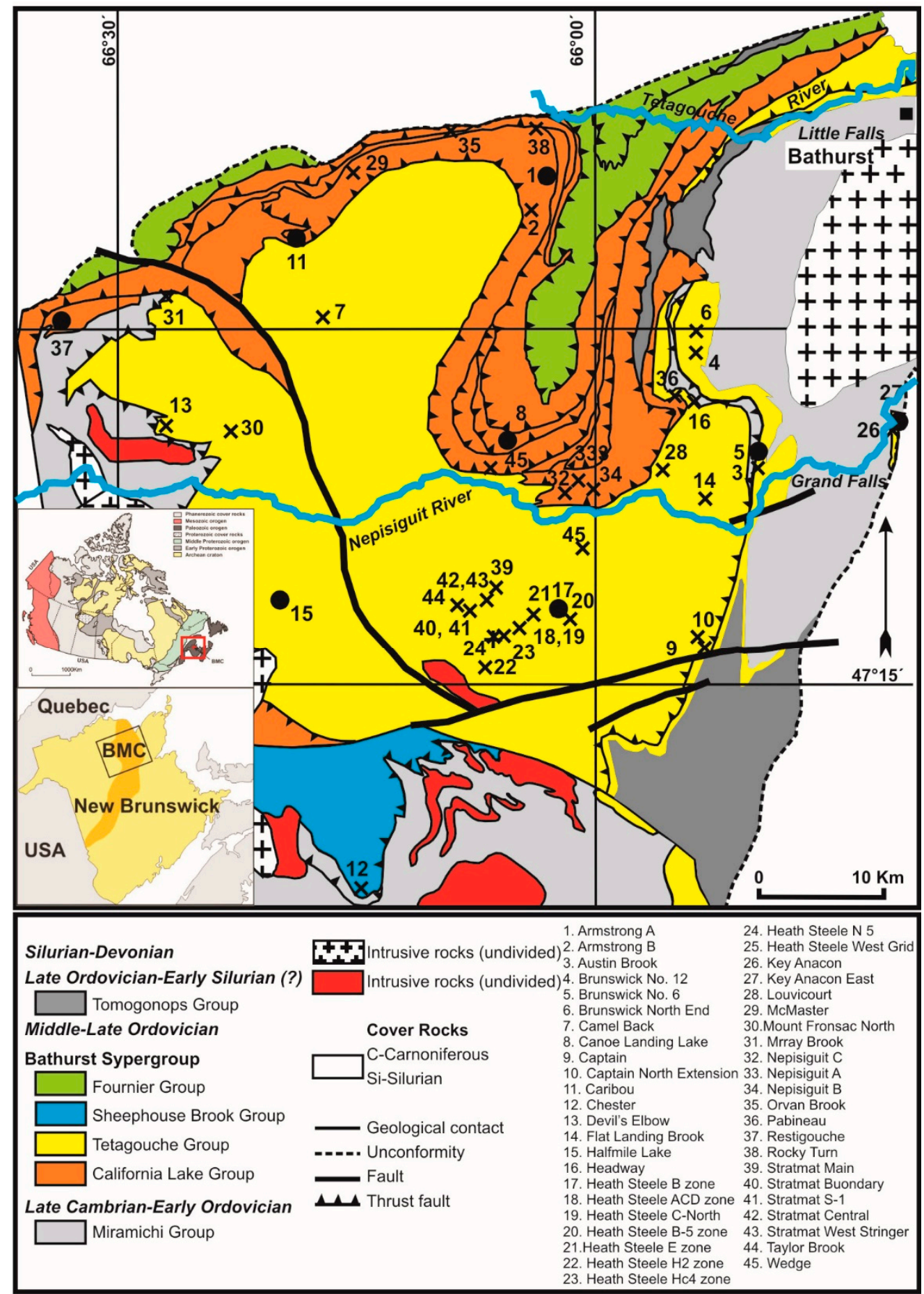

Figure 1. Simplified geological map of the Bathurst Mining Camp, northeastern New Brunswick, showing the location of massive sulphide deposits examined during this study (black circles) (modified from [26,29]).

In general, the massive sulphide samples of the BMC are fine-grained and texturally complex. Thus, targeting individual minerals for LA-Q-ICP-MS trace-element or isotope measurements necessitates crater diameters in the 20 (or less) to $70 \mu \mathrm{m}$ range. The selected samples contain 
predominantly five minerals that comprise $95 \%$ of the rock: pyrite, sphalerite, galena, chalcopyrite, and pyrrhotite. Minor amounts of arsenopyrite, marcasite, and tetrahedrite-tennantite, are also present and sulphosalts occur at trace levels. In the VMS deposits of the BMC, galena occurs as blebs, veins, disseminations, and inclusions associated with other phases. Regional metamorphic effects and the relative softness and ductility of galena explain why it occurs interstitial to other phases in BMC deposits. The proportion of galena is higher in the bedded $\mathrm{Zn}-\mathrm{Pb}$ sulphide facies than in the bedded pyrite and vent complex facies (see [21] and references therein) (Figure 2).
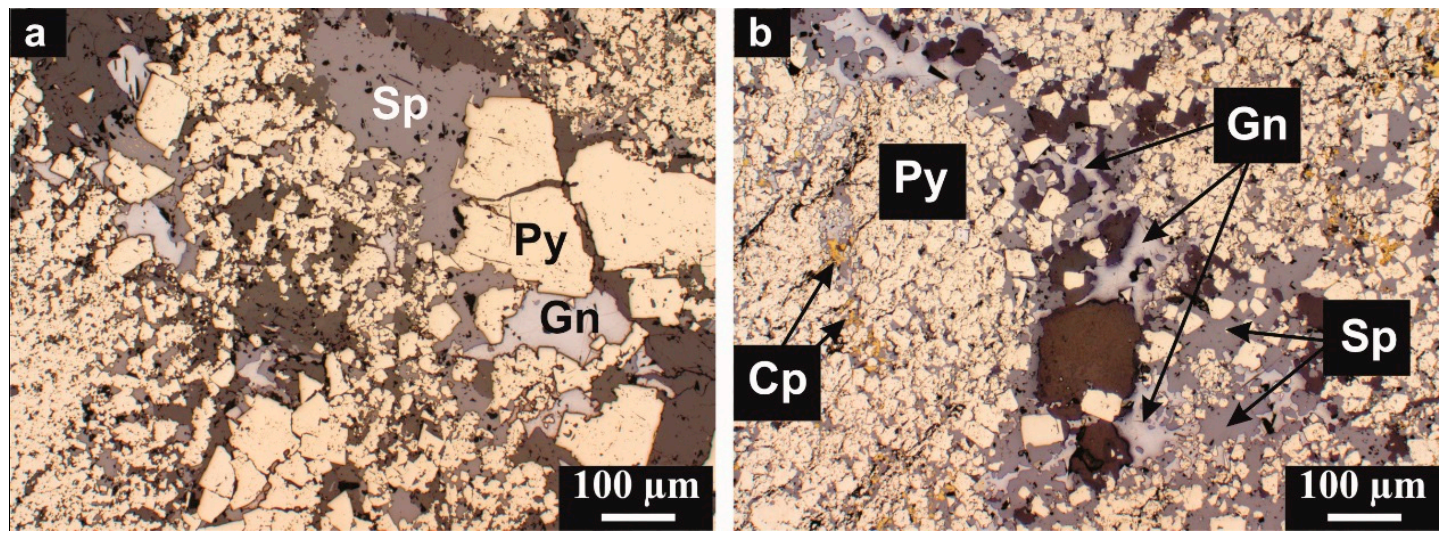

Figure 2. Photomicrographs (plane-polarized reflected light) of representative samples from massive sulphide deposits of the BMC. (a) A massive sulphide sample containing intergrowth of galena (Gn) with sphalerite (Sp). Sample is from drill hole 62-55-115 @ $35.2 \mathrm{~m}$ (Caribou deposit). (b) A bedded sulphide sample containing masses of sphalerite, showing intergrowth with pyrite (Py) and galena. Sample is from drill hole 94-DL-32@ 402 m (Key Anacon East zone deposit).

\section{Methodology}

\section{1. $L A-Q-I C P-M S$ Instrumentation}

The LA Q-ICP-MS instrumentation at the Department of Earth Sciences, University of New Brunswick, Fredericton, Canada includes an ASI (formerly Resonetics) Resolution ${ }^{\text {TM }}$ M-50 193 nm ArF (excimer) laser system (Canberra, Australia) synchronized to an Agilent 7700x quadrupole inductively coupled plasma mass spectrometer equipped with dual external rotary pumps. The system has been described in detail in a number of previous publications (e.g., [30,31]). Ablation is conducted into a two-volume low-volume Laurin Technic Pty S-155 sample cell capable of holding six $45 \times 25 \mathrm{~mm}$ polished thin sections and five $25 \mathrm{~mm}$ round standard pucks. The cell is repeatedly evacuated and backfilled with He to remove traces of air from the cell after each sample exchange. Ablated aerosol is transported out of the cell using $300 \mathrm{~mL} / \mathrm{min} \mathrm{He}$ and $930 \mathrm{~mL} / \mathrm{min}$ Ar that is carried to the ICP-MS in $4 \mathrm{~mm}$ OD Nylon ${ }^{\mathrm{TM}}$ tubing. A Laurin Technic Pty "Squid" smoothing device (Canberra, Australia) was placed mid-way between the ablation cell and the ICP-MS torch. No carry-over of Pb was observed from one ablation to the next or on a day-to-day timescale despite total $\mathrm{Pb}$ ion beams of $>1 \times 10^{8} \mathrm{cps}$.

The ICP-MS was operated at $1550 \mathrm{~W}$ and a torch depth of $4.0 \mathrm{~mm}$. The ICP-MS was tuned, while rastering across NIST610 glass, to achieve $\mathrm{ThO}^{+} / \mathrm{Th}^{+}<0.15 \%$ (monitor of oxide production), ${ }^{238} \mathrm{U}^{+} /{ }^{232} \mathrm{Th}^{+} \sim 1.0$ (monitor of plasma robustness), and ${ }^{44} \mathrm{Ca}^{++} /{ }^{44} \mathrm{Ca}^{+}<0.3 \%$ (monitor of double-charged production). This tuning step was also used to establish lens settings and carrier gas flows that yielded a raw ${ }^{207} \mathrm{~Pb} /{ }^{206} \mathrm{~Pb}$ for NIST610 that overlapped the accepted value $(0.9095 \pm 0.0005)$. The ICP-MS is equipped with a dual-mode discrete dynode detector with a pulse counting mode for low ion beam intensities $\left(<2 \times 10^{6} \mathrm{cps}\right)$ and an analogue mode for high-intensity signals. Thus the pulse-analogue factors $(\mathrm{P} / \mathrm{A})$ are set for each analyte in the acquisition at the start of every new sequence (or when detector voltages are adjusted) by rastering across NIST610 and varying the spot size and repetition rate to obtain $\sim 2 \times 10^{6} \mathrm{cps}$ for each analyte so that the cross-over between detector 
modes can be calibrated. In the case of galena analysed here, all $\mathrm{Pb}$ masses were recorded in analogue mode, whereas $\mathrm{Ag}, \mathrm{Hg}$, $\mathrm{Tl}, \mathrm{Th}$, and $\mathrm{U}$ were collected in pulse mode.

\subsection{Ablation Condition}

Ablation conditions were additionally optimized by trial-and-error for the acquisition of $\mathrm{Pb}$ isotopes of galena. Galena has a low melting point, so that a low and stable energy density setting is critical in order to avoid the effects of incomplete vaporization and ionization of large particles in the plasma [5,32,33]. In addition, the size of ablation crater is important with respect to improving the accuracy and precision, and for control downhole fractionation: craters with high diameter/depth ratio (e.g., >10) typically yield minimal fractionation and more steady-state signals. This near-steady-state signal ensures that the sequential counting of the relevant isotopes is measured on a time-invariant (or nearly so) ion beam.

The first round of $\mathrm{Pb}$ isotope data were obtained under the conditions of $23 \mu \mathrm{m}$ diameter crater size, $25 \mathrm{~s}$ ablation with a laser pulse rate of $3 \mathrm{~Hz}$, and a fluence of $\sim 1 \mathrm{~J} / \mathrm{cm}^{2}$ as measured using a hand-held energy meter above the ablation cell (Table 1). At least 20 ablations on galena per sample were obtained, although some that hit inclusions were discarded. This short ablation time on galena was based on the observation that after $20 \mathrm{~s}$ the signal became very noisy, presumably because of zone heating, melting, and spalling of agglomerates. A background collection time of $60 \mathrm{~s}$ was used to allow for washout of the high-intensity $\mathrm{Pb}$ signal, so that accurate $\mathrm{Hg}$ and $\mathrm{Pb}$ background levels could be determined prior to the next ablation. Errors resulting from surface contamination due to polishing of sulphides are inevitable, but can be typically eliminated by pre-ablating spots with a single laser pulse that removes $\sim 100 \mathrm{~nm}$ of material and allowing $10 \mathrm{~s}$ for washout. The isotopes measured in the first round included ${ }^{200} \mathrm{Hg},{ }^{201} \mathrm{Hg},{ }^{202} \mathrm{Hg},{ }^{203} \mathrm{Tl},{ }^{204}(\mathrm{~Pb}+\mathrm{Hg}),{ }^{205} \mathrm{Tl},{ }^{206} \mathrm{~Pb},{ }^{207} \mathrm{~Pb}$, ${ }^{208} \mathrm{~Pb},{ }^{232} \mathrm{Th}$, and ${ }^{238} \mathrm{U}$. Individual dwell times were set at $100 \mathrm{~ms}$ except for ${ }^{208} \mathrm{~Pb}(50 \mathrm{~ms})$ and ${ }^{232} \mathrm{Th}$ and ${ }^{238} \mathrm{U}(20 \mathrm{~ms})$. The total quadrupole sweep time per measurement (including detector dead-time and settling time) was $0.89 \mathrm{~s}$. This extended list of analytes was chosen so that a full assessment of instrumental mass-bias was possible and an accurate ${ }^{204} \mathrm{Hg}$ correction could be obtained. For example, the isotopes of $\mathrm{Hg}$ can be used to apply (if necessary) a mass-bias correction to the ${ }^{202} \mathrm{Hg} /{ }^{204} \mathrm{Hg}$ based on the measured/reference ${ }^{200} \mathrm{Hg} /{ }^{201} \mathrm{Hg}$ or ${ }^{203} \mathrm{Tl} /{ }^{205} \mathrm{Tl}$ ratio. Correcting for mass bias prior to ${ }^{204} \mathrm{Hg}$ peak-stripping in this way should provide the most accurate net ${ }^{204} \mathrm{~Pb}$ ion beam measurement.

In the second round of analysis of the same samples, the ablation conditions were changed to $44 \mu \mathrm{m}$ diameter crater size, $40 \mathrm{~s}$ ablation time, $\sim 0.35 \mathrm{~J} / \mathrm{cm}^{2}$ fluence and a laser pulse rate of $2 \mathrm{~Hz}$ (Table 1). The lower laser fluence conditions showed very controlled ablation and low \%RSD signals for the $\mathrm{Pb} / \mathrm{Pb}$ ratios. In this run, ${ }^{203} \mathrm{Tl},{ }^{238} \mathrm{U}$ and ${ }^{232} \mathrm{Th}$ were not included because the results of the first analytical session showed that $U$ and Th are sufficiently low in galena that they have no measurable effect on the $\mathrm{Pb}$ isotope ratios. Although $\mathrm{Tl}$ is a potentially important substituent in galena, the measured ${ }^{203} \mathrm{Tl} /{ }^{205} \mathrm{Tl}$ ratio was too imprecise for assessment of mass bias. The dwell times of the analytes were reduced to give a total quadrupole sweep time of $0.33 \mathrm{~s}$. This is necessary to avoid the isotope ratios "pulsing" when $2 \mathrm{~Hz}$ laser frequency is used and increased the total number of measurements per ablation up to 120 .

Finally, all of the samples were analysed using a $60 \mu \mathrm{m}$ diameter crater size and $60 \mathrm{~s}$ ablation time, but with all other parameters kept constant as the second round (Table 1). Silver $\left({ }^{107} \mathrm{Ag}\right)$ was additionally analyzed and added to the analyte list. Increasing the diameter of the ablation crater improved the errors even more as a result of larger ion beams measured with minimal loss of intensity over the duration of the ablation. In addition, ablation of galena with varying crater sizes $(23,44$ and $60 \mu \mathrm{m})$, provides a good test of the reproducibility of the method and a plot of the error on weighted mean of $\mathrm{Pb}$ isotopic ratios versus crater size suggests that additional increases in the crater size and ablation time could help to incrementally decrease weighted mean errors to $<0.1 \%$ $2 \sigma$ (Figure 3). In addition, a plot comparing differences in ablation results for $23 \mathrm{vs.} 60 \mu \mathrm{m}$ diameter craters and 1 vs. $0.35 \mathrm{~J} / \mathrm{cm}^{2}$ shows increases in sensitivity, more controlled ablation, lower \%RSD signals, and consequently higher precision (Figure 4). 
Table 1. LAICP-MS Pb isotope ratios (all data) for galena from representative massive sulphide deposits of the BMC.

\begin{tabular}{|c|c|c|c|c|c|c|c|c|c|c|c|c|}
\hline No. & Deposit & Drill Hole & ${ }^{206} \mathrm{~Pb} /{ }^{204} \mathrm{~Pb}$ & $2 \sigma$ & ${ }^{207} \mathrm{~Pb} /{ }^{204} \mathrm{~Pb}$ & $2 \sigma$ & ${ }^{208} \mathrm{P} /{ }^{204} \mathrm{~Pb}$ & $2 \sigma$ & ${ }^{207} \mathrm{~Pb} /{ }^{206} \mathrm{~Pb}$ & $2 \sigma$ & ${ }^{206} \mathrm{~Pb} /{ }^{208} \mathrm{~Pb}$ & $2 \sigma$ \\
\hline \multicolumn{13}{|c|}{ Ablation condition: $23 \mu \mathrm{m}, 3 \mathrm{~Hz}, 1 \mathrm{~J} \cdot \mathrm{cm}^{-2}, 25 \mathrm{~s}$ ablation duration } \\
\hline$n=20$ & Caribou & $62-55-115$ & 18.294 & 0.044 & 15.738 & 0.044 & 38.270 & 0.100 & 0.8593 & 0.0022 & 0.4783 & 0.001 \\
\hline$n=19$ & Key Anacon East zone & 94-DL-32 & 18.243 & 0.040 & 15.725 & 0.043 & 38.320 & 0.120 & 0.8623 & 0.0020 & 0.4769 & 0.001 \\
\hline$n=20$ & Brunswick No. 6 & B-259 & 18.155 & 0.038 & 15.628 & 0.043 & 38.060 & 0.110 & 0.8627 & 0.0020 & 0.4762 & 0.001 \\
\hline$n=20$ & Restigouche & СР39-123 & 18.181 & 0.037 & 15.680 & 0.037 & 38.090 & 0.100 & 0.8621 & 0.0021 & 0.4771 & 0.001 \\
\hline$n=20$ & Halfmile Lake Deep zone & HN-119 & 18.157 & 0.044 & 15.568 & 0.045 & 38.070 & 0.110 & 0.8614 & 0.0023 & 0.4765 & 0.001 \\
\hline \multicolumn{13}{|c|}{ Ablation condition: $44 \mu \mathrm{m}, 2 \mathrm{~Hz}, 0.35 \mathrm{~J} \cdot \mathrm{cm}^{-2}, 40 \mathrm{~s}$ ablation duration } \\
\hline$n=18$ & Caribou & $62-55-115$ & 18.193 & 0.038 & 15.663 & 0.033 & 38.120 & 0.100 & 0.8572 & 0.0015 & 0.4787 & 0.001 \\
\hline$n=20$ & Key Anacon East zone & 94-DL-32 & 18.156 & 0.026 & 15.595 & 0.030 & 38.082 & 0.097 & 0.8599 & 0.0015 & 0.4773 & 0.001 \\
\hline$n=20$ & Brunswick No. 6 & B-259 & 18.123 & 0.031 & 15.668 & 0.033 & 38.000 & 0.100 & 0.8605 & 0.0016 & 0.4793 & 0.001 \\
\hline$n=19$ & Restigouche & CP39-123 & 18.320 & 0.030 & 15.697 & 0.033 & 38.140 & 0.100 & 0.8586 & 0.0015 & 0.4784 & 0.001 \\
\hline$n=9$ & Halfmile Lake Deep zone & HN-99-119 & 18.170 & 0.042 & 15.611 & 0.048 & 38.000 & 0.140 & 0.8594 & 0.0023 & 0.4794 & 0.002 \\
\hline \multicolumn{13}{|c|}{ Ablation condition: $60 \mu \mathrm{m}, 2 \mathrm{~Hz}, 0.35 \mathrm{~J} \cdot \mathrm{cm}^{-2}, 60 \mathrm{~s}$ ablation duration } \\
\hline$n=23$ & Caribou & $62-55-115$ & 18.264 & 0.018 & 15.637 & 0.021 & 38.170 & 0.068 & 0.8563 & 0.0010 & 0.4782 & 0.001 \\
\hline$n=20$ & Caribou & $62-55-115$ & 18.267 & 0.019 & 15.645 & 0.016 & 38.157 & 0.046 & 0.8566 & 0.00063 & 0.4783 & 0.001 \\
\hline$n=20$ & Key Anacon East zone & 94-DL-32 & 18.190 & 0.016 & 15.634 & 0.015 & 38.130 & 0.059 & 0.8589 & 0.00073 & 0.4765 & 0.001 \\
\hline$n=20$ & Brunswick No. 6 & B-259 & 18.203 & 0.017 & 15.653 & 0.016 & 38.070 & 0.047 & 0.8603 & 0.00062 & 0.4781 & 0.001 \\
\hline$n=20$ & Restigouche & СР39-123 & 18.247 & 0.017 & 15.673 & 0.016 & 38.185 & 0.047 & 0.8586 & 0.00065 & 0.4786 & 0.001 \\
\hline$n=20$ & Halfmile Lake Deep zone & HN-119 & 18.203 & 0.017 & 15.661 & 0.017 & 38.135 & 0.048 & 0.8606 & 0.00063 & 0.4763 & 0.001 \\
\hline \multicolumn{13}{|c|}{ Reference values $[34,35]$} \\
\hline \multicolumn{3}{|c|}{ Brunswick No. 12} & 18.187 & 0.018 & 15.649 & 0.016 & 38.10 & 0.04 & & & & \\
\hline \multicolumn{3}{|c|}{ Austin Brook } & 18.247 & 0.018 & 15.658 & 0.016 & 38.14 & 0.04 & & & & \\
\hline \multicolumn{3}{|c|}{ Heath Steele A1 } & 18.199 & 0.018 & 15.652 & 0.016 & 38.12 & 0.04 & & & & \\
\hline \multicolumn{3}{|c|}{ Stratmat } & 18.207 & 0.018 & 15.641 & 0.016 & 38.12 & 0.04 & & & & \\
\hline \multicolumn{3}{|c|}{ Wedge } & 18.275 & 0.018 & 15.662 & 0.016 & 38.20 & 0.04 & & & & \\
\hline \multicolumn{3}{|c|}{ Armstrong A } & 18.287 & 0.018 & 15.655 & 0.016 & 38.17 & 0.04 & & & & \\
\hline \multicolumn{3}{|c|}{ Rocky Turn } & 18.319 & 0.018 & 15.668 & 0.016 & 38.27 & 0.04 & & & & \\
\hline \multicolumn{3}{|c|}{ Orvan Brook } & 18.305 & 0.018 & 15.653 & 0.016 & 38.20 & 0.04 & & & & \\
\hline \multicolumn{3}{|c|}{ Murry Brook } & 18.309 & 0.018 & 15.669 & 0.016 & 38.22 & 0.04 & & & & \\
\hline \multicolumn{3}{|c|}{ Chester } & 18.302 & 0.018 & 15.659 & 0.016 & 38.22 & 0.04 & & & & \\
\hline \multicolumn{3}{|c|}{ Strachans Lake BK. } & 18.223 & 0.018 & 15.649 & 0.016 & 38.19 & 0.04 & & & & \\
\hline \multicolumn{3}{|c|}{ Canoe Landing Lake } & 18.243 & 0.018 & 15.653 & 0.016 & 38.19 & 0.04 & & & & \\
\hline \multicolumn{3}{|c|}{ Willett Showing } & 18.295 & 0.018 & 15.651 & 0.016 & 38.19 & 0.04 & & & & \\
\hline
\end{tabular}


Table 1. Cont.

\begin{tabular}{|c|c|c|c|c|c|c|c|c|c|c|c|}
\hline Deposit & Drill Hole & ${ }^{206} \mathrm{~Pb} /{ }^{204} \mathrm{~Pb}$ & $2 \sigma$ & ${ }^{207} \mathrm{~Pb} /{ }^{204} \mathrm{~Pb}$ & $2 \sigma$ & ${ }^{208} \mathrm{P} /{ }^{204} \mathrm{~Pb}$ & $2 \sigma$ & ${ }^{207} \mathrm{~Pb} /{ }^{206} \mathrm{~Pb}$ & $2 \sigma$ & ${ }^{206} \mathrm{~Pb} /{ }^{208} \mathrm{~Pb}$ & $2 \sigma$ \\
\hline Armstrong B & & 18.298 & 0.018 & 15.660 & 0.016 & 38.23 & 0.04 & & & & \\
\hline Portage Lakes & & 18.230 & 0.018 & 15.647 & 0.016 & 38.14 & 0.04 & & & & \\
\hline Captain & & 18.279 & 0.018 & 15.657 & 0.016 & 38.16 & 0.04 & & & & \\
\hline Brunswick No. 6 & & 18.277 & 0.018 & 15.663 & 0.016 & 38.22 & 0.04 & & & & \\
\hline Key Anacon & & 18.247 & 0.018 & 15.658 & 0.016 & 38.14 & 0.04 & & & & \\
\hline Caribou & & 18.276 & 0.018 & 15.654 & 0.016 & 38.19 & 0.04 & & & & \\
\hline Halfmile Lake & & 18.217 & 0.018 & 15.659 & 0.016 & 38.15 & 0.04 & & & & \\
\hline Restigouche & & 18.241 & 0.018 & 15.648 & 0.016 & 38.16 & 0.04 & & & & \\
\hline \multicolumn{12}{|c|}{ Reference values [36] } \\
\hline Wedge & & 18.281 & 0.007 & 15.725 & 0.01 & 38.159 & 0.01 & & & & \\
\hline Heath Steele & & 18.229 & 0.007 & 15.658 & 0.01 & 38.13 & 0.01 & & & & \\
\hline Brunswick 12 & & 18.237 & 0.007 & 15.671 & 0.01 & 38.203 & 0.01 & & & & \\
\hline Restigouche & & 18.257 & 0.007 & 15.7 & 0.01 & 38.197 & 0.01 & & & & \\
\hline
\end{tabular}

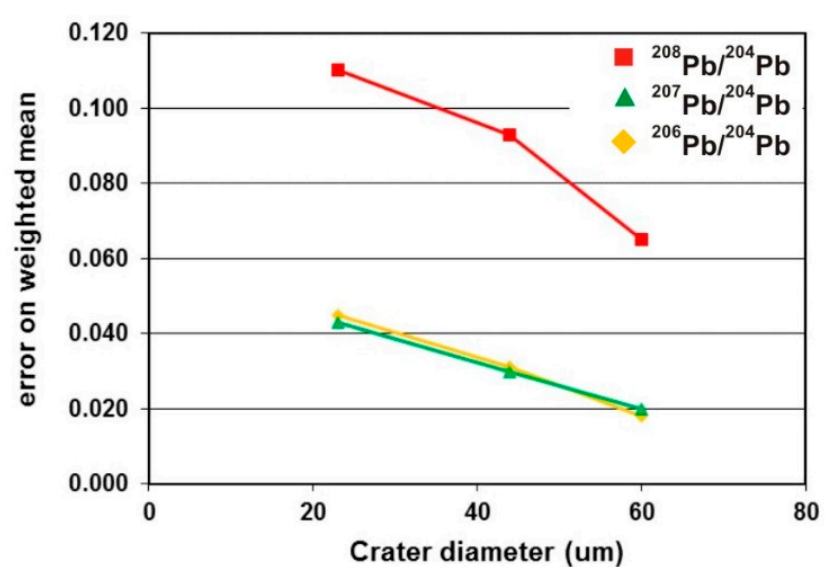

Figure 3. Plot of the error on weighted mean of Pb isotopic ratios vs. crater size (sample 62-55-115, Caribou deposit). 


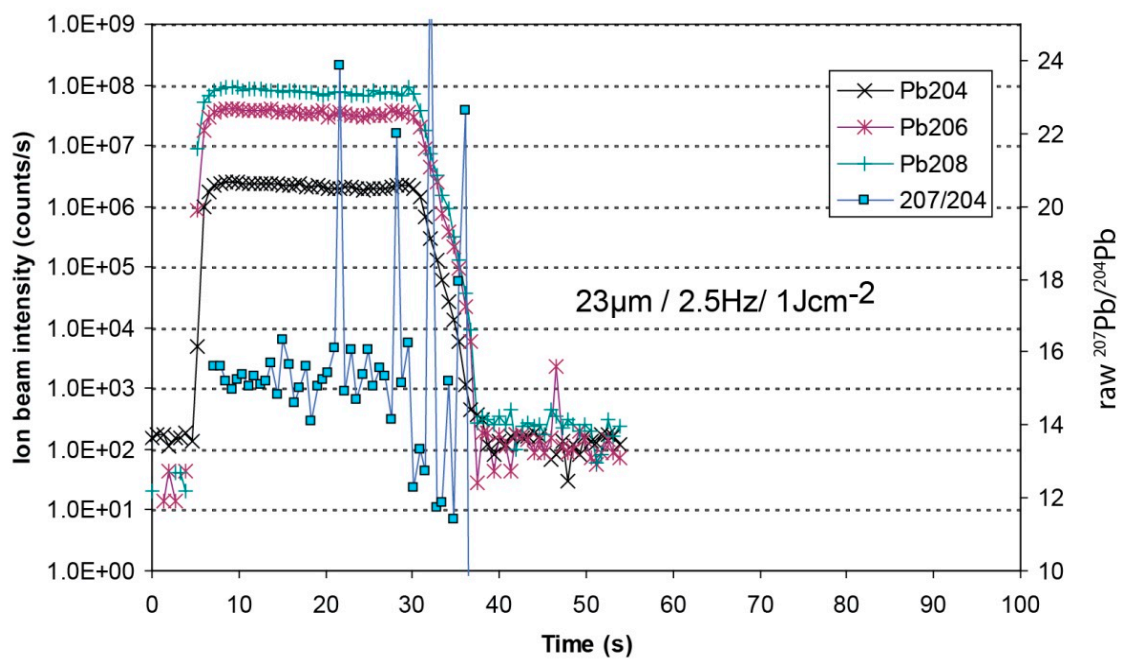

(a)

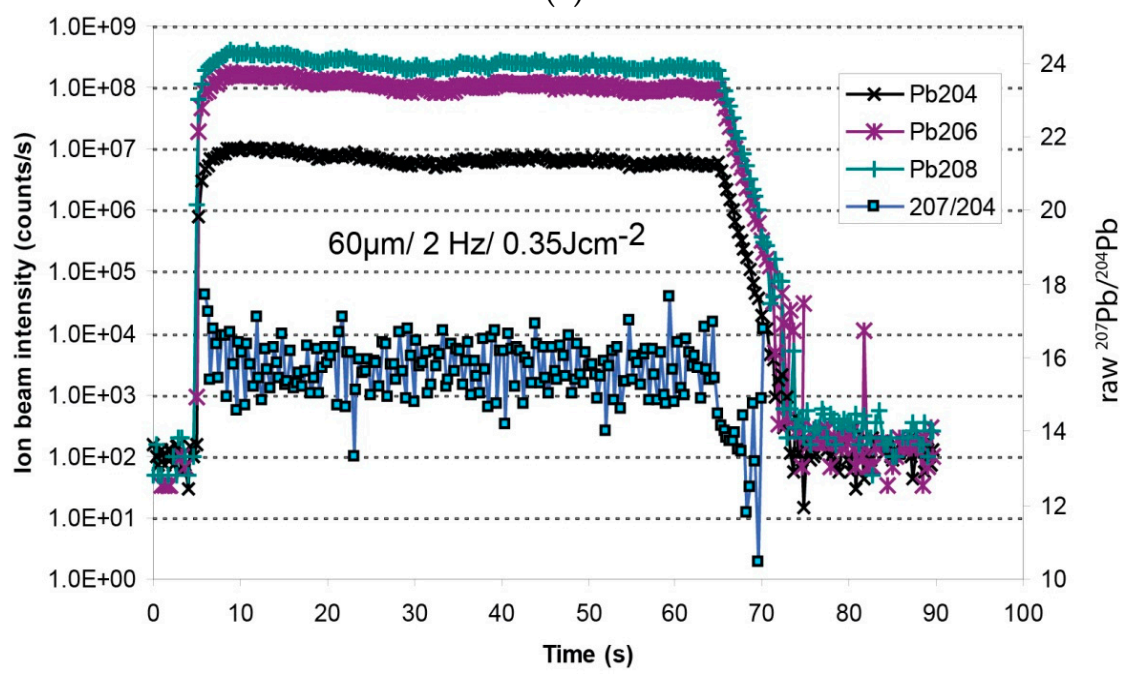

(b)

Figure 4. Comparison of results of different ablation condition of galena: (a) $23 \mu \mathrm{m}, 2.5 \mathrm{~Hz}$, and $1 \mathrm{~J} \cdot \mathrm{cm}^{-2}$; and (b) $60 \mu \mathrm{m}, 2 \mathrm{~Hz}$, and $0.35 \mathrm{~J} \cdot \mathrm{cm}^{-2}$.

\section{Standardization}

The use of NIST glasses for external calibration of sulphide compositional data has been examined previously (e.g., $[37,38])$; however, a reference material with sulphide-based composition is preferred (e.g., $[33,39,40])$. Unfortunately, there has been only limited investigation of matrix matching issues in the context of $\mathrm{Pb}$ isotope analyses of sulphides (see [41]). Natural in-house pyrite standards were preferred by [5] rather than NIST glasses to provide a matrix-matched standardization approach. Recently, Pb isotopic ratios for the standard MASS-1 have been reported (GeoReM database); however, using MASS-1 is not a common approach in data reduction of Pb-isotope of sulphides. Examining MASS-1 during this study shows that the high $\mathrm{Hg}$ (compared to other targets) causes long washout for $\mathrm{Hg}(\sim 5 \mathrm{~min})$ that raises backgrounds and obscures low-level $\mathrm{Hg}$ signals during ablation of unknowns. Following [5], we standardized the galena $\mathrm{Pb}$-isotope measurements relative to an in-house Broken Hill galena [42] to ensure matrix-matching. The reference values for Broken Hill galena were taken from [42]. Since the ablation was performed at low energy density, effects of matrix-mismatching are expected to be significant [5]. Thus, although MASS-1 and other glass standards (610 and GSE1-G) were analysed in the first session for comparison, the results displayed significant laser-induced biases 
that could not be corrected. NIST610 does not ablate under the laser fluence of $0.35 \mathrm{~J} \cdot \mathrm{cm}^{-2}$ used for the 44 and $60 \mu \mathrm{m}$ laser crater diameter sessions.

Data were collected in 2 to $4 \mathrm{~h}$ long runs with standards evenly spaced after every ten unknowns to allow an accurate instrument drift correction. The measured raw $\mathrm{Pb}-\mathrm{Pb}$ ratios on Broken Hill galena show no significant drift, although sensitivity did decrease over the course of the runs (based on the total ion beam measured on BH galena). The integrations for the standard (Broken Hill) and unknowns were inspected offline and the integration selected based on the lowest internal error (2 S.E.) on the ${ }^{207} \mathrm{~Pb} /{ }^{204} \mathrm{~Pb}$ ratio, which typically comprised all but a $2 \mathrm{~s}$ rise time at the start of the ablation. One of the challenges of $\mathrm{Pb}$ isotope measurement is inherent difficulties related to resolving the interference effect of ${ }^{204} \mathrm{Hg}$ on the ${ }^{204} \mathrm{~Pb}$ signal at low concentration. In addition, $\mathrm{Hg}$ impurities in the carrier gases have been an issue for many laser-based ICP-MS laboratories [43]. At the University of New Brunswick, all carrier gas lines are fitted with dedicated high-capacity (up to $20 \mathrm{~L} / \mathrm{min}$ ) in-line $\mathrm{Hg}$ traps and maintenance and cleaning of the instrument is conducted on the routine basis. The ${ }^{202} \mathrm{Hg}$ gas backgrounds remain $<400 \mathrm{cps}$ under the highest sensitivity conditions. In the analysed galena, the $\mathrm{Hg}$ occurs in low concentrations (up to $3.2 \mathrm{ppm}$, unpublished data from the LA-ICP-MS analysis on galena, BMC), so induced-Hg interference is not a significant issue.

Offline data reduction was conducted using Iolite ${ }^{\mathrm{TM}}$ (http:/ / www.iolite.org.au; [44]) running as a plugin in Wavemetrics IgorPro 6.32 ${ }^{\mathrm{TM}}$ software (http:/ / www.wavemetrics.com). Iolite facilitates visualization of ion beam intensities versus time and allows integration of specific portions of the ablated signal. Consequently, inclusions and surface related impurities can be avoided. Of the several data reduction schemes developed for Iolite, calculation of $\mathrm{Pb}$ isotopes was tested using two approaches: the VizualAge DRS [45] and Laser_Pb_Faraday. VizualAge applies a drift correction, but no downhole fractionation correction to the $\mathrm{Pb}$-isotope ratios and uses an empirical correction, based on the measured/true values of the standard to correct the isotope ratios for instrumental mass bias. The Laser_Pb_Faraday approach is designed for multiple-collector ICP-MS instruments and uses a fractionation correction, based on the measured/true value on the standard and an assumed exponential fractionation that is a function of the mass difference between isotopes: $k=(1 / \Delta \mathrm{m}) \ln \left(R_{\mathrm{m}} / R_{\mathrm{t}}\right)$ where $\Delta \mathrm{m}$ is the mass difference and $R_{\mathrm{m}}$ and $R_{\mathrm{t}}$ are measured and true ratios, respectively. Using the background to calculate both ${ }^{200} \mathrm{Hg} /{ }^{202} \mathrm{Hg}$ and ${ }^{201} \mathrm{Hg} /{ }^{202} \mathrm{Hg}$ and assuming canonical values of 0.7736 and 0.4414 , the mean exponential factor $(k)$ for the first analytical session is $0.0009 \pm 0.0030$. This implies negligible instrumental mass bias over this mass range. A similar result was obtained for ${ }^{203} \mathrm{Tl} /{ }^{205} \mathrm{Tl}$ (canonical value $=0.4189$ ) measured on MASS-1. The measured $/$ true ${ }^{203} \mathrm{Tl} /{ }^{205} \mathrm{Tl}$ yielded a weighted mean of $1.000 \pm 0.051$, again implying negligible mass bias over this mass range. Finally, raw $\mathrm{Pb}-\mathrm{Pb}$ values on Broken Hill galena are very close to the assumed true values. The measured ${ }^{206} \mathrm{~Pb} /{ }^{204} \mathrm{~Pb},{ }^{207} \mathrm{~Pb} /{ }^{204} \mathrm{~Pb},{ }^{208} \mathrm{~Pb} /{ }^{204} \mathrm{~Pb}$, and ${ }^{207} \mathrm{~Pb} /{ }^{206} \mathrm{~Pb}$ values for Broken Hill were within $\sim 2 \%$ of the true values, attesting to a small, but measureable mass bias for the $\mathrm{Pb}$ mass range under the analytical conditions employed. This mass bias varies from day-to-day and future work will involve an additional tuning step on Broken Hill galena to obtain ion lens settings that minimize mass bias. Thus, because of the small mass bias and matrix-matched nature of the external calibration, a simple empirical correction similar to that employed by VizualAge is preferred compared to an exponential-type mass bias correction.

Typically, the precision of quadrupole ICP systems in determination of Pb isotopes is low compared to multi-collector systems. This can be compensated, to some extent, by increasing the number of spot analysis and pooling the data, ensuring that the mean square weighted deviations (MSWD) on the weighted average (using the Isoplot software; [46]) remains below 1.3 [47]. To ensure fully propagated errors, at least 15 standards need to be run. Figure 5 shows probability density plots of the $\mathrm{Pb}$ isotopes of galena from the Halfmile Lake Deep zone. The measured $\mathrm{Pb}$ isotope ratios are demonstrably normally distributed justifying the use of weighted means for the populations. All errors in Table 1 are reported at the $95 \%$ confidence interval. 

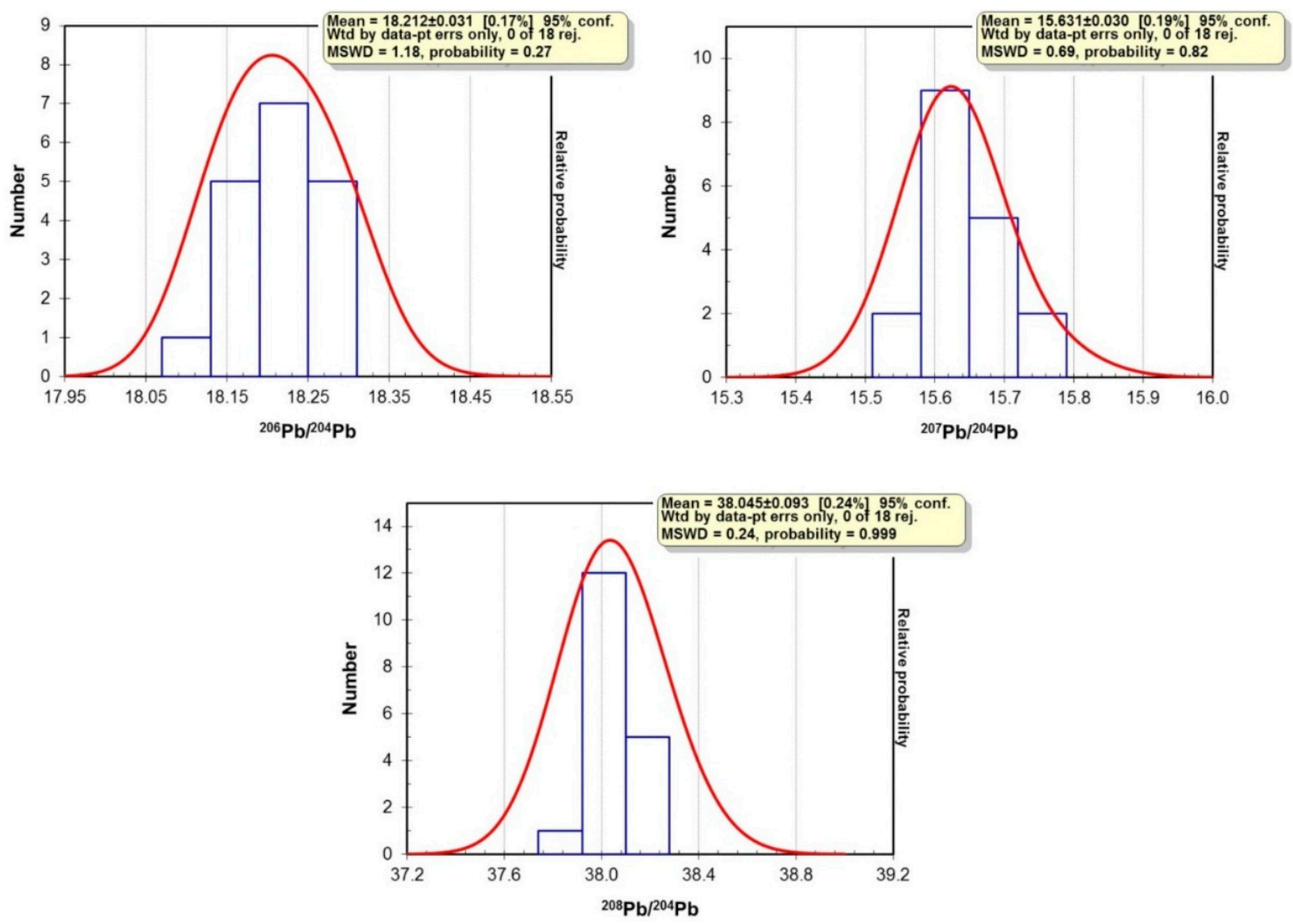

Figure 5. Probability density plots of $\mathrm{Pb}$ isotope ratios of galena from the Caribou deposit. MSWD stands for Mean Square Weighted Deviations.

\section{Results}

The $\mathrm{Pb}$ isotope composition of galena $(n=308)$ from representative massive sulphide deposits of the BMC is summarized in Table 1 and the whole dataset in Supplementary Materials 1, along with reference values for the BMC VMS deposits based on the unpublished conventional whole-rock $\mathrm{Pb}-\mathrm{Pb}$ data collected by the Geological Survey of Canada [34-36].

The data are reported herein as drift and externally corrected values relative to Broken Hill galena standard with fully propagated $2 \sigma(95 \% \mathrm{CI})$ errors on the weighted means. Weighted means were calculated by Isoplot for the ${ }^{206} \mathrm{~Pb} /{ }^{204} \mathrm{~Pb},{ }^{207} \mathrm{~Pb} /{ }^{204} \mathrm{~Pb},{ }^{208} \mathrm{~Pb} /{ }^{204} \mathrm{~Pb},{ }^{207} \mathrm{~Pb} /{ }^{206} \mathrm{~Pb}$ and ${ }^{206} \mathrm{~Pb} /{ }^{208} \mathrm{~Pb}$ ratios. The mean ${ }^{202} \mathrm{Hg}$ ion beam in galena was $<10 \mathrm{cps}$, whereas ${ }^{207} \mathrm{~Pb}$ was $\sim 3.0 \times 10^{6}$ icps (integrated count per second). The data for the BMC samples show a range of $\mathrm{Pb}$ isotope ratios that are unique to each deposit, consistent with the previously documented array of $\mathrm{Pb}$-isotope values recorded for the BMC. This array of values is distinguishable at both $44 \mu \mathrm{m}$ and $60 \mu \mathrm{m}$ crater diameters, with the latter having better precision. The results are plotted on conventional ${ }^{207} \mathrm{~Pb} /{ }^{204} \mathrm{~Pb}$ vs. ${ }^{206} \mathrm{~Pb} /{ }^{204} \mathrm{~Pb}$ and ${ }^{208} \mathrm{~Pb} /{ }^{204} \mathrm{~Pb}$ vs. ${ }^{206} \mathrm{~Pb} /{ }^{204} \mathrm{~Pb}$ diagrams, showing the variation of $\mathrm{Pb}$ isotopic ratios based on the [48] (Figure 6) and relative to the terrestrial $\mathrm{Pb}$-isotope growth curve [49] and other terrestrial reservoirs from [48]. Error correlations between ${ }^{206} \mathrm{~Pb} /{ }^{204} \mathrm{~Pb}$ vs. ${ }^{207} \mathrm{~Pb} /{ }^{204} \mathrm{~Pb}$ and ${ }^{206} \mathrm{~Pb} /{ }^{204} \mathrm{~Pb}$ vs. ${ }^{208} \mathrm{~Pb} /{ }^{204} \mathrm{~Pb}$ are currently not reported by VizualAge, but estimated correlation coefficients of 0.0003 and 0.001 , respectively, were calculated from each final corrected dataset. An error correlation of 0.1 was assumed for the conventional data for the BMC. The results of galena ablation with $44 \mu \mathrm{m}$ crater sizes shows that galena from Restigouche yields the most radiogenic ${ }^{207} \mathrm{~Pb} /{ }^{204} \mathrm{~Pb}$ ratio (15.697), whereas galena from Key Anacon East zone yields the lowest ${ }^{207} \mathrm{~Pb} /{ }^{204} \mathrm{~Pb}$ ratio (15.595). The ${ }^{208} \mathrm{~Pb} /{ }^{204} \mathrm{~Pb}$ ratio is highest in galena from the Restigouche deposit (38.140) and the lowest in galena from Halfmile Lake Deep zone and Brunswick No. 6 (38.000). The ${ }^{206} \mathrm{~Pb} /{ }^{204} \mathrm{~Pb}$ results are highest in galena from Restigouche (18.320) and the lowest in galena from Brunswick No. 6 (18.123). 

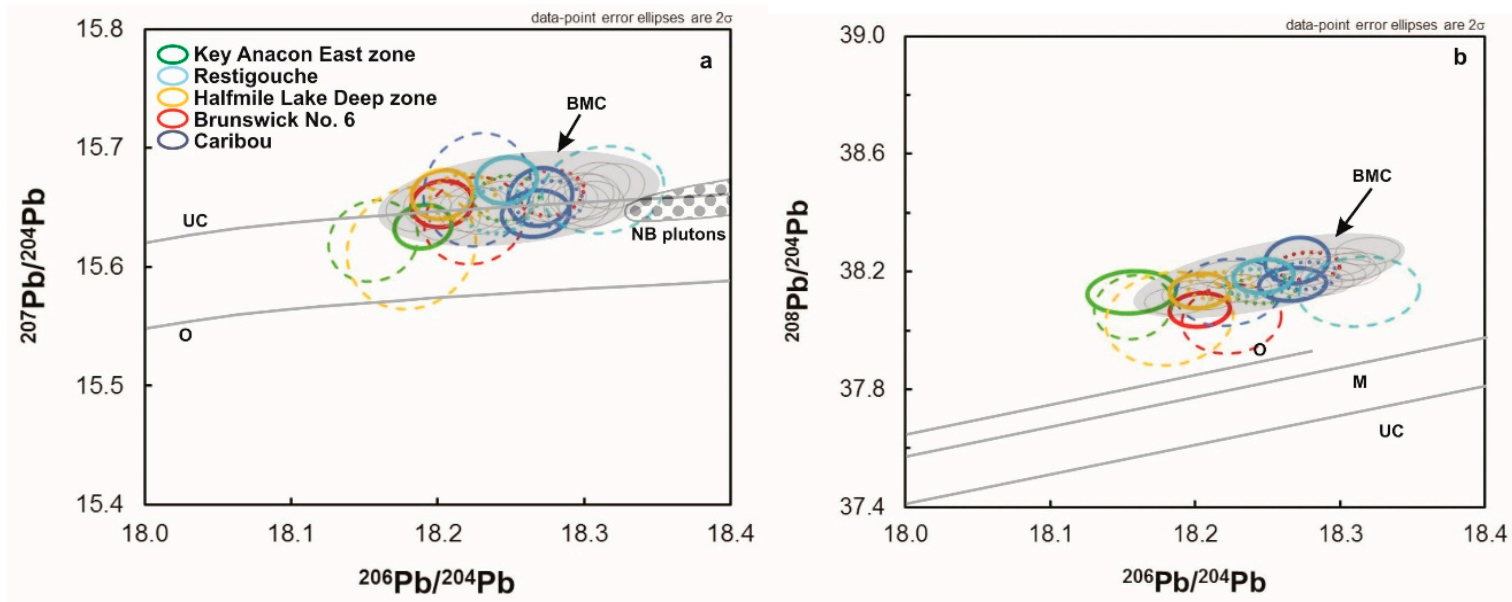

Figure 6. Plot of ${ }^{206} \mathrm{~Pb} /{ }^{204} \mathrm{~Pb}$ versus (a) ${ }^{207} \mathrm{~Pb} /{ }^{204} \mathrm{~Pb}$ and (b) ${ }^{208} \mathrm{~Pb} /{ }^{204} \mathrm{~Pb}$ of galena by LA-Q-ICP-MS from representative massive sulphide deposits of the $\mathrm{BMC}$. The $\mathrm{Pb}$ isotopic ratios presented for BMC VMS (grey area) ([34-36] (R.I. Thorpe, unpublished data), [48]) and New Brunswick, Canada (NB pluton) [50]. The average $\mathrm{Pb}$ evolution curves for mantle $(\mathrm{M})$, orogene $(\mathrm{O})$, and upper crust (UC) are from [48]. Thick dashed lines present the ablation of galena under the $44 \mu \mathrm{m}, 2 \mathrm{~Hz}$, and $1 \mathrm{~J} \cdot \mathrm{cm}^{-2}$ condition. Thick solid lines present the ablation of galena under the $60 \mu \mathrm{m}, 2 \mathrm{~Hz}$, and $0.35 \mathrm{~J} \cdot \mathrm{cm}^{-2}$ condition. Dotted line presents the reference values of $\mathrm{Pb}$ isotopes of examined deposits for comparison ([34]).

\section{Discussion}

\subsection{Limits of Precision and Accuracy}

In contrast to previous studies that attempted to analyse Pb isotopes in galena by LA-ICP-MS, we have shown that fluence $>1 \mathrm{~J} \cdot \mathrm{cm}^{-2}$, repetitions rates $>3 \mathrm{~Hz}$, and $<30 \mu \mathrm{m}$ crater diameters are sub-optimal for controlled ablation of galena. Here, optimization at 44 and $60 \mu \mathrm{m}$ diameter craters produced more accurate and precise data, with $\mathrm{Pb}-\mathrm{Pb}$ data for all five samples falling within or just outside the main $\mathrm{BMC} \mathrm{Pb}-\mathrm{Pb}$ array, especially in ${ }^{206} \mathrm{~Pb} /{ }^{204} \mathrm{~Pb}$ versus ${ }^{208} \mathrm{~Pb} /{ }^{204} \mathrm{~Pb}$ space. Isotopic differences among deposits are resolvable and all data measured by LA-Q-ICP-MS clearly points to an upper crustal source of $\mathrm{Pb}$. Ablation of galena samples at $60 \mu \mathrm{m}$ diameter resulted in an error on the pooled data that is on par with conventional $\mathrm{Pb}-\mathrm{Pb}$ data: $2 \sigma$ errors of $\sim 0.10 \%$ on ${ }^{206} \mathrm{~Pb} /{ }^{204} \mathrm{~Pb}$ and ${ }^{207} \mathrm{~Pb} /{ }^{206} \mathrm{~Pb}, \sim 0.13 \%$ on ${ }^{207} \mathrm{~Pb} /{ }^{204} \mathrm{~Pb}$ and ${ }^{206} \mathrm{~Pb} /{ }^{208} \mathrm{~Pb}$, and $\sim 0.18 \%$ on ${ }^{208} \mathrm{~Pb} /{ }^{204} \mathrm{~Pb}$. The errors on ${ }^{207} \mathrm{~Pb} /{ }^{204} \mathrm{~Pb}$ and ${ }^{208} \mathrm{~Pb} /{ }^{204} \mathrm{~Pb}$ could be further improved by using better optimized dwell times for ${ }^{206} \mathrm{~Pb},{ }^{207} \mathrm{~Pb}$, and ${ }^{208} \mathrm{~Pb}$.

Whereas the measurements clearly fall within error of the regional BMC array, there remain inconsistencies between the measured and reference values on a deposit scale. Whereas data for the Halfmile Lake and Caribou deposits overlap within error the conventional values, we measured anomalously low ${ }^{206} \mathrm{~Pb} /{ }^{204} \mathrm{~Pb}$ for Brunswick No. 6 and Key Anacon East zone and anomalously high ${ }^{206} \mathrm{~Pb} /{ }^{204} \mathrm{~Pb}$ for Restigouche. The Brunswick No. 6 deposit also gave a lower than expected ${ }^{208} \mathrm{~Pb} /{ }^{204} \mathrm{~Pb}$ value. There was, however, a significant improvement of both the precision and accuracy of isotope ratios measured for the Caribou deposit using a $60 \mu \mathrm{m}$ diameter crater. Thus, further testing at larger crater diameter (if possible given the grain size distribution) may help resolve some of these inconsistencies. It is nonetheless possible that there is a measureable difference between the conventional whole-rock data and the in situ data given the possibility of mixing between different $\mathrm{Pb}$-isotope sources (e.g., host-rock volcaniclastic detritus vs. hydrothermal mineralization) using a bulk sampling approach. If these differences are still manifest once the LA-Q-ICP-MS measurements are further optimized, in situ testing using high precision LA-MC-ICP-MS may be warranted to resolve the different source components in these deposits. As discussed below, this approach could provide new insight into the VMS deposits exploration. 


\subsection{Exploration Implications}

$\mathrm{Pb}$ isotopic studies have been applied as a powerful tool in exploration of metallogenic terrains ([6] and references therein). The $\mathrm{Pb}$ isotopic investigation of mineral systems is based on comparing the isotopic compositions of existing deposits within a district to prospective showings. In these situations, the $\mathrm{Pb}$-isotope signature can assist in differentiating among mineralization types, as well as the scale of deposition [6,51,52]. In ancient mineralization occurrences, the difference between mean $\mathrm{Pb}$ isotopic compositions of ore and host rocks increased with time. Thus, in metamorphic terrains, $\mathrm{Pb}$ isotope signatures can potentially help in tracing footprints of major mineralization $([51,52]$ and references therein).

The microanalytical method described here provides rapid screening of galena, with levels of accuracy and precision to establish the Pb-isotopic composition of galena with respect to camp-scale $\mathrm{Pb}-\mathrm{Pb}$ arrays. Although galena was the focus of this study, other Pb-bearing sulphides (pyrite, sphalerite, chalcopyrite) could also be targeted if grain sizes are sufficiently large to permit the use of large ablation craters to obtain $>10^{6} \mathrm{cps}$ of ${ }^{207} \mathrm{~Pb}$. This methodology can be applied in determination of $\mathrm{Pb}$ isotopic compositions of a wide range of sulphide phases occurring in the ore horizons, the associated host rocks, iron formation, and surficial materials. By assessing the background level of $\mathrm{Pb}$ isotopes of the main sulphide horizons, any systematic variation in $\mathrm{Pb}$ isotopes within the host rock or sediments can be potentially used as a vectoring tool in VMS exploration [53]. Variations in $\mathrm{Ag}$ / $\mathrm{Tl}$ or other trace metals in galena (e.g., $\mathrm{Cd}$, In, and $\mathrm{Te}$ ) analysed simultaneously with $\mathrm{Pb}$ isotopes could also reveal petrogenetically distinct pulses of galena mineralization. Hence, this approach provides a complementary technique to conventional $\mathrm{Pb}$ isotope methods and to other geochemical exploration tools applied to VMS deposits.

Foremost, this study has established important instrumental settings necessary to achieve the highest possible precision and accuracy on $\mathrm{Pb}$-isotopes analysed in situ by laser ablation, independent of the ICP-MS platform. Critically, the use of low laser fluence, low laser pulse rate, and an expanded analyte list that includes isotopes of $\mathrm{Ag}, \mathrm{Hg}, \mathrm{Tl}, \mathrm{Pb}, \mathrm{Th}$, and $\mathrm{U}$ are important features of the development of this method. Internal precision could be further improved by using larger laser craters (e.g., >60 $\mu \mathrm{m}$ ) when galena grain size is amenable. Additional optimization could include measurement of key elemental discriminants, such as concentrations of $\mathrm{Ag}, \mathrm{Cd}, \mathrm{Te}, \mathrm{Tl}$, and $\mathrm{Bi}$. Extension of this approach to in situ analysis using higher-sensitivity sector-field ICP-MS or to multiple-collector (MC)-ICP-MS equipped with an array of ion counters and Faraday detectors would be expected to reduce internal precision significantly, potentially to variations at the $<0.1 \%$ level on individual spots and $<0.05 \%$ on weighted means for pooled results. This level of precision is ideally required for more detailed $\mathrm{Pb}$-isotope investigations, especially in samples where several textural generations of galena are present. Independent of the plasma-source platform; however, optimization of ablation conditions on galena is critically important in ensuring precise and accurate data.

\section{Conclusions}

The methodology outlined herein offers a robust technique for the evaluation of the Pb isotopes in galena. This approach allows rapid data acquisition and correction, with sufficient precision and accuracy to resolve $\mathrm{Pb}$-isotope differences among a suite of massive sulphide deposits. In VMS deposits of the $\mathrm{BMC}, \mathrm{Pb}$ isotopes are typified by radiogenic signatures related to derivation from an upper crust (including metasedimentary components) lead reservoir with minor mixing with a mantle or orogene source. This approach can be potentially applied as a reconnaissance tool for VMS exploration to identify sulphide mineralization that lies along regional $\mathrm{Pb}-\mathrm{Pb}$ arrays associated with major deposits. Further refinement of the technique is required; however, results thus far suggest that accurate and relative precise $\mathrm{Pb}$-isotope analysis by LA-Q-ICP-MS is now within reach.

Supplementary Materials: The following are available online at www.mdpi.com/2075-163X/6/3/96/s1. 
Acknowledgments: We gratefully acknowledge the Geological Survey of Canada for funding this project through NRCan TGI-4 (Targeted Geoscience Initiative IV) program grant to David R. Lentz and Christopher R.M. McFarlane. We sincerely appreciate colleagues at the Geological Survey of Canada; particularly Jan Peter (VMS Ore System Science Leader) for his cooperation and advice. We also appreciate colleagues at New Brunswick Department of Energy and Resource Development in Bathurst, especially Jim Walker and Sean McClenaghan for assistance in locating previous dataset and samples. We are deeply thankful to Walker for English proofreading and suggestions on the first draft. We are grateful to Brandon Boucher at the final stage of the project, assisting in LA-ICP-MS laboratory at the University of New Brunswick. We acknowledge anonymous reviewers for their meticulous and constructive reviews of the draft manuscript.

Author Contributions: Christopher R.M. McFarlane designed and carried out the LA-ICP-MS analysis, data correction and developments of methodology, and contributed in interpretations and writing. Azam Soltani Dehnavi conducted the sample selection, petrography, and prepared the first manuscript. David R. Lentz provided samples and contributed in interpretations and writing.

Conflicts of Interest: The authors declare no conflict of interest.

\section{References}

1. Cook, N.J.; Ciobanu, C.L.; Mao, J. Textural control on gold distribution in As-free pyrite from the Dongping, Huangtuliang and Hougou gold deposits, North China Craton (Hebei Province, China). Chem. Geol. 2009, 264, 101-121. [CrossRef]

2. George, L.; Cook, N.J.; Ciobanu, C.L.; Wade, B.P. Trace and minor elements in galena: A reconnaissance LA-ICP-MS study. Am. Mineral. 2015, 100, 548-569. [CrossRef]

3. Large, R.R.; Meffre, S.; Burnett, R.; Guy, B.; Bull, S.; Gilbert, S.; Goemann, K.; Danyushevsky, L. Evidence for an intrabasinal source and multiple concentration processes in the formation of the Carbon Leader Reef, Witwatersrand Supergroup, South Africa. Econ. Geol. 2013, 108, 1215-1241. [CrossRef]

4. Meffre, S.; Large, R.R.; Scott, R.; Woodhead, J.; Chang, Z.; Gilbert, S.E.; Danyushevsky, L.V.; Maslennikov, V.; Hergt, J.M. Age and pyrite Pb-isotopic composition of the giant Sukhoi Log sediment-hosted gold deposit, Russia. Geochim. Cosmochim. Acta 2008, 72, 2377-2391. [CrossRef]

5. Woodhead, J.; Hergt, J.; Meffre, S.; Large, R.R.; Danyushevsky, L.; Gilbert, S. In situ Pb-isotope analysis of pyrite by laser ablation (multi-collector and quadrupole) ICPMS. Chem. Geol. 2009, 262, 344-354. [CrossRef]

6. Champion, D.C.; Huston, D.L. Radiogenic isotopes, ore deposits and metallogenic terranes: Novel approaches based on regional isotopic maps and the mineral systems concept. Ore Geol. Rev. 2016, 76, 229-256. [CrossRef]

7. Velasco, F.; Pesquera, A.; Herrero, J.M. Lead isotope study of $\mathrm{Zn}-\mathrm{Pb}$ ore deposits associated with the Basque-Cantabrian basin and Paleozoic basement, Northern Spain. Mineral. Depos. 1996, 31, 84-92. [CrossRef]

8. Swinden, H.S.; Thorpe, R. Variations in style of volcanism and massive sulphide deposition in Early to Middle Ordovician island-arc sequences of the Newfoundland Central Mobile Belt. Econ. Geol. 1984, 79, 1596-1619. [CrossRef]

9. Townsend, A.; Hutton, J. Precise lead isotope ratios in Australian galena samples by high resolution inductively coupled plasma mass spectrometry. J. Anal. At. Spectrom. 1998, 13, 809-813. [CrossRef]

10. Ayuso, R.; Kelley, K.; Leach, D.; Young, L.; Slack, J.; Wandless, J.; Lyon, A.; Dillingham, J. Origin of the Red Dog Zn-Pb-Ag Deposits, Brooks Range, Alaska: Evidence from Regional Pb and Sr Isotope Sources. Econ. Geol. 2004, 99, 1533-1553. [CrossRef]

11. Tessalina, S.G.; Herrington, R.J.; Taylor, R.N.; Sundblad, K.; Maslennikov, V.V.; Orgeval, J. Lead isotopic systematics of massive sulphide deposits in the Urals: Applications for geodynamic setting and metal sources. Ore Geol. Rev. 2016, 72, 22-36. [CrossRef]

12. Mathez, E.; Waight, T.E. Lead isotopic disequilibrium between sulphide and plagioclase in the Bushveld Complex and the chemical evolution of large layered intrusions. Geochim. Cosmochim. Acta 2003, 67, 1875-1888. [CrossRef]

13. Mathez, E.; Kent, A. Variable initial Pb isotopic compositions of rocks associated with the UG2 chromitite, eastern Bushveld Complex. Geochim. Cosmochim. Acta 2007, 71, 5514-5527. [CrossRef]

14. McNaughton, N. Lead-Isotope Systematics for Archaean Sulphide Studies: Recent Advances to Understanding Precambrian Gold Deposits; Geology Department and University Extension, University of Western Australia Publication: Crawley, Australia, 1987; pp. 181-188. 
15. Ho, S.E.; McNaughton, N.J.; Groves, D.I. Criteria for determining initial lead isotopic compositions of pyrite in Archaean lode-gold deposits: A case study at Victory, Kambalda, Western Australia. Chem. Geol. 1994, 111, 57-84. [CrossRef]

16. Olivo, G.R.; Isnard, H.; Williams-Jones, A.E.; Gariépy, C. Pb isotope compositions of pyrite from the C quartz-tourmaline vein of the Siscoe gold deposit, Val d'Or, Quebec: Constraints on the origin and age of the gold mineralization. Econ. Geol. 2007, 102, 137-146. [CrossRef]

17. Qiu, Y.; McNaughton, N. Source of $\mathrm{Pb}$ in orogenic lode-gold mineralisation: $\mathrm{Pb}$ isotope constraints from deep crustal rocks from the southwestern Archaean Yilgarn Craton, Australia. Mineral. Depos. 1999, 34, 366-381. [CrossRef]

18. Efimenko, N.; Schneider, J.; Spangenberg, J.E.; Chiaradia, M.; Adatte, T.; Föllmi, K.B. Formation and age of sphalerite mineralization in carbonate rocks of Bajocian age in the Swiss Jura Mountains: Evidence of Mesozoic hydrothermal activity. Int. J. Earth Sci. 2014, 103, 1059-1082. [CrossRef]

19. Ayuso, R.; Wooden, J.; Foley, N.; Slack, J.; Sinha, A.; Persing, H. Pb isotope geochemistry and U-Pb zircon (SHRIMP-RG) ages of the Bald Mountain and Mount Chase massive sulphide deposits, northern Maine; mantle and crustal contributions in the Ordovician: Massive sulphide deposits of the Bathurst Mining Camp. In Massive Sulfide Deposits of the Bathurst Mining Camp, New Brunswick, and Northern Maine; Goodfellow, W.D., McCutcheon, S.R., Peter, J.M., Eds.; Society of Exploration Geophysicists Geophysical Monograph Series 11; Society of Economic Geologists, Inc.: Littleton, CO, USA, 2003; pp. 589-609.

20. Habicht-Mauche, J.A.; Glenn, S.T.; Schmidt, M.P.; Franks, R.; Milford, H.; Flegal, A.R. Stable lead isotope analysis of Rio Grande glaze paints and ores using ICP-MS: A comparison of acid dissolution and laser ablation techniques. J. Archaeol. Sci. 2002, 29, 1043-1053. [CrossRef]

21. Goodfellow, W.D.; McCutcheon, S. Geologic and genetic attributes of volcanic sediment-hosted massive sulphide deposits of the Bathurst Mining Camp, northern New Brunswick-A synthesis. In Massive Sulfide Deposits of the Bathurst Mining Camp, New Brunswick, and Northern Maine; Society of Exploration Geophysicists Geophysical Monograph Series 11; Society of Economic Geologists, Inc.: Littleton, CO, USA, 2003; pp. 245-301.

22. Van Staal, C.R.; Williams, P. Structure, origin, and concentration of the Brunswick 12 and 6 orebodies. Econ. Geol. 1984, 79, 1669-1692. [CrossRef]

23. Van Staal, C.R.; Winchester, J.A.; Bedard, J.H. Geochemical variations in Middle Ordovician volcanic rocks of the northern Miramichi Highlands and their tectonic significance. Can. J. Earth Sci. 1991, 28, 1031-1049. [CrossRef]

24. Van Staal, C.R.; Winchester, J.A.; Cullen, R. Evidence for D1-related thrusting and folding in the Bathurst-Millstream River area, New Brunswick. Geol. Surv. Can. Pap. 1988, 88-1B, 135-148.

25. Van Staal, C.R.; Wilson, R.; Rogers, N.; Fyffe, L.; Gower, S.; Langton, J.; McCutcheon, S.; Walker, J.A. A new geologic map of the Bathurst Mining Camp and surrounding areas-A product of integrated geological, geochemical, and geophysical data. In Massive Sulfide Deposits of the Bathurst Mining Camp, New Brunswick, and Northern Maine; Goodfellow, W.D., McCutcheon, S.R., Peter, J.M., Eds.; Society of Exploration Geophysicists Geophysical Monograph Series 11; Society of Economic Geologists, Inc.: Littleton, CO, USA, 2003; pp. 61-64.

26. Van Staal, C.R.; Wilson, R.; Rogers, N.; Fyffe, L.; Langton, J.; McCutcheon, S.; McNicoll, V.; Ravenhurst, C. Geology and tectonic history of the Bathurst Supergroup, Bathurst Mining Camp, and its relationships to coeval rocks in southwestern New Brunswick and adjacent Maine-A synthesis. In Massive Sulfide Deposits of the Bathurst Mining Camp, New Brunswick, and Northern Maine; Goodfellow, W.D., McCutcheon, S.R., Peter, J.M., Eds.; Society of Exploration Geophysicists Geophysical Monograph Series 11; Society of Economic Geologists, Inc.: Littleton, CO, USA, 2003; pp. 37-60.

27. Van Staal, C.R.; Currie, K.; Rowbotham, G.; Rogers, N.; Goodfellow, W. Pressure-temperature paths and exhumation of Late Ordovician-Early Silurian blueschists and associated metamorphic nappes of the Salinic Brunswick subduction complex, northern Appalachians. Geol. Soc. Am. Bull. 2008, 120, 1455-1477. [CrossRef]

28. Currie, K.; van Staal, C.R.; Peter, J.; Rogers, N. Conditions of metamorphism of the main massive sulphide deposits and surrounding host rocks in the Bathurst Mining Camp: Massive Sulphide Deposits of the Bathurst Mining Camp, New Brunswick, and Northern Maine. In Massive Sulfide Deposits of the Bathurst Mining Camp, New Brunswick, and Northern Maine; Goodfellow, W.D., McCutcheon, S.R., Peter, J.M., Eds.; Society of Exploration Geophysicists Geophysical Monograph Series 11; Society of Economic Geologists, Inc.: Littleton, CO, USA, 2003; pp. 65-78. 
29. Walker, J.A.; McCutcheon, S.R. A chemostratigraphic assessment of core from the discovery hole of the Halfmile Lake Deep VMS Zone, Bathurst Mining Camp, northeastern New Brunswick. In Geological Investigations in New Brunswick for 2010; Martin, G.L., Ed.; Mineral Resource Report; New Brunswick Department of Natural Resources, Lands, Minerals and Petroleum Division: Fredricton, NB, Canada, 2011; Volume 2, pp. 1-49.

30. McFarlane, C.R.; Luo, Y. U-Pb geochronology using $193 \mathrm{~nm}$ excimer LA-ICP-MS optimized for in-situ accessory mineral dating in thin sections. Geosci. Can. 2012, 39, 158-172.

31. McFarlane, C.R.; McKeough, M. Petrogenesis of the Kulyk Lake monazite-apatite-Fe (Ti)-oxide occurrence revealed using in-situ LA-(MC)-ICP-MS trace element mapping, U-Pb dating, and Sm-Nd isotope systematics on monazite. Am. Mineral. 2013, 98, 1644-1659. [CrossRef]

32. Jackson, S.E.; Günther, D. The nature and sources of laser induced isotopic fractionation in laser ablation-multicollector-inductively coupled plasma-mass spectrometry. J. Anal. At. Spectrom. 2003, 18, 205-212. [CrossRef]

33. Wohlgemuth-Ueberwasser, C.C.; Ballhaus, C.; Berndt, J.; Stotter née Paliulionyte, V.; Meisel, T. Synthesis of PGE sulphide standards for laser ablation inductively coupled plasma mass spectrometry (LA-ICP-MS). Contrib. Mineral. Petrol. 2007, 154, 607-617. [CrossRef]

34. Thorpe, R.I.; Franklin, J.M.; Sangster, D.F. Evolution of lead in massive sulphide ores of Bathurst district, New Brunswick, Canada. Trans. Inst. Min. Metall. 1981, 90B, 55-56.

35. McCutcheon, S.R.; Langton, J.P.; van Staal, C.R.; Lenz, D.R. Stratigraphy, tectonic setting and massive-sulphide deposits of the Bathurst mining camp, northern New Brunswick. In Proceedings of the Bathurst '93, Annual Field Conference 3rd, Geological Society of Mining, Metallurgy and Petroleum, Bathurst, NB, Canada, 9-11 September 1993; pp. 1-28.

36. Leybourne, M.I.; Cousens, B.L.; Goodfellow, W.D. Lead isotopes in ground and surface waters: Fingerprinting heavy metal sources in mineral exploration. Geochem. Explor. Environ. Anal. 2009, 9, 115-123. [CrossRef]

37. Halter, W.E.; Heinrich, C.A.; Pettke, T. Laser-ablation ICP-MS analysis of silicate and sulphide melt inclusions in an andesitic complex II: Evidence for magma mixing and magma chamber evolution. Contrib. Mineral. Petrol. 2004, 147, 397-412. [CrossRef]

38. Sylvester, P.J. Matrix effects in laser ablation ICP-MS. In Laser Ablation ICP-MS in the Earth Sciences: Current Practices and Outstanding Issues; Sylvester, P., Ed.; Mineralogical Association Canada: Quebec, QC, Canada, 2008; Volume 40, pp. 67-78.

39. Wilson, S.A.; Ridley, W.I.; Koenig, A.E. Development of sulphide calibration standards for the laser ablation inductively-coupled plasma mass spectrometry technique. J. Anal. At. Spectrom. 2002, 17, 406-409. [CrossRef]

40. Danyushevsky, L.; Robinson, P.; Gilbert, S.; Norman, M.; Large, R.; McGoldrick, P.; Shelley, M. Routine quantitative multi-element analysis of sulphide minerals by laser ablation ICP-MS: Standard development and consideration of matrix effects. Geochem. Explor. Environ. Anal. 2011, 11, 51-60. [CrossRef]

41. Norman, M.; McCulloch, M.; O’Neill, H.S.C.; Yaxley, G. Magnesium isotopic analysis of olivine by laser-ablation multi-collector ICP-MS: Composition dependent matrix effects and a comparison of the Earth and Moon. J. Anal. At. Spectrom. 2006, 21, 50-54. [CrossRef]

42. Stacey, J.S.; Delevaux, M.A.; Ulrych, T.J. Some triple-filament lead isotope ratio measurements and an absolute growth curve for single-stage leads. Earth Planet. Sci. Lett. 1969, 6, 15-25. [CrossRef]

43. Košler, J.; Sylvester, P.J. Present trends and the future of zircon in geochronology: Laser ablation ICPMS. Rev. Mineral. Geochem. 2003, 53, 243-275.

44. Paton, C.; Hellstrom, J.; Paul, B.; Woodhead, J.; Hergt, J. Iolite: Freeware for the visualisation and processing of mass spectrometric data. J. Anal. At. Spectrom. 2011, 26, 2508-2518. [CrossRef]

45. Petrus, J.A.; Kamber, B.S. VizualAge: A Novel Approach to Laser Ablation ICP-MS U-Pb Geochronology Data Reduction. Geostand. Geoanal. Res. 2012, 36, 247-270. [CrossRef]

46. Ludwig, K.R. Isoplot 3.1: A Geochronological Toolkit for Microsoft Excel; Berkeley Geochronological Centre Special Publication: Berkeley, CA, USA, 2003; p. 70.

47. Wendt, I.; Carl, C. The statistical distribution of the mean squared weighted deviation. Chem. Geol. Isot. Geosci. Sect. 1991, 86, 275-285. [CrossRef]

48. Doe, B.R.; Zartman, R.E. Plumbotectonics, the Phanerozoic. In Geochemistry of Hydrothermal Ore Deposits, 2nd ed.; Barnes, H.L., Ed.; Wiley-Interscience: New York, NY, USA, 1979; pp. 22-70. 
49. Stacey, J.T.; Kramers, J.D. Approximation of terrestrial lead isotope evolution by a two-stage model. Earth Planet. Sci. Lett. 1975, 26, 207-221. [CrossRef]

50. Whalen, J.B.; Rogers, N.; van Staal, C.R.; Longstaffe, F.J.; Jenner, G.A.; Winchester, J.A. Geochemical and isotopic $(\mathrm{Nd}, \mathrm{O})$ data from Ordovician felsic plutonic and volcanic rocks of the Miramichi Highlands: Petrogenetic and metallogenic, implications for the Bathurst Mining Camp. Can. J. Earth Sci. 1998, 35, 237-252. [CrossRef]

51. Peretti, A.; Köppel, V. Geochemical and lead isotope evidence for a mid-ocean ridge type mineralization within a polymetamorphic ophiolite complex (Monte del Forno, North Italy/Switzerland). Earth Planet. Sci. Lett. 1986, 80, 252-264. [CrossRef]

52. Loveless, A. Lead isotopes-A guide to major mineral deposits. Geoexploration 1975, 13, 13-27. [CrossRef]

53. Hussein, A.A.; Lochner, C.; Bell, K. Application of Pb Isotopes to Mineral Exploration in the Halfmile Lake Area, Bathurst, New Brunswick. In Massive Sulfide Deposits of the Bathurst Mining Camp, New Brunswick, and Northern Maine; Goodfellow, W.D., McCutcheon, S.R., Peter, J.M., Eds.; Society of Exploration Geophysicists Geophysical Monograph Series 11; Society of Economic Geologists, Inc.: Littleton, CO, USA, 2003; pp. 679-688.

(C) 2016 by the authors; licensee MDPI, Basel, Switzerland. This article is an open access article distributed under the terms and conditions of the Creative Commons Attribution (CC-BY) license (http://creativecommons.org/licenses/by/4.0/). 